\title{
Synthesis, Structure, and Catalytic Activity of A New Mn(II) Complex with 1,4-Phenylenediacetic Acid and 1,10-Phenanthroline
}

\author{
Li-Hua Wang1*, Peng-Fei Li ${ }^{2}$ \\ ${ }^{1}$ College of Information and Engineering, Weifang University, Weifang 261061, P.R. China \\ ${ }^{2}$ College of Chemical Engineering, Qingdao University of Science and Technology, Qingdao 266061, \\ P.R. China
}

Received: $5^{\text {th }}$ March 2017; Revised: $7^{\text {th }}$ June 2017; Accepted: $12^{\text {nd }}$ July 2017

Available online: 22 $2^{\text {nd }}$ January 2018; Published regularly: $2^{\text {nd }}$ April 2018

\begin{abstract}
A new $\mathrm{Mn}$ (II) complex material has been synthesized by one-pot reaction of $\mathrm{Mn}\left(\mathrm{CH}_{3} \mathrm{COO}\right)_{2} \cdot 4 \mathrm{H}_{2} \mathrm{O}, 1$,4phenylenediacetic $\left(\mathrm{H}_{2} \mathrm{~L}\right), 1,10$-phenanthroline (phen), and $\mathrm{NaOH}$ in water/ethanol (v:v = 1:1) solution. The structure of $\mathrm{Mn}$ (II) complex was determined by elemental analysis, FTIR, and X-ray single-crystal diffraction analysis. The results reveal that $\mathrm{Mn}$ (II) complex was constructed by a monodentate 1,4phenylenediacetate ligand, two phen ligands, a coordinated water molecule, 0.5 uncoordinated 1,4phenylenediacetate ligand and six uncoordinated water molecules. The complex molecules form 1D chain structure by the $\pi-\pi$ interaction of phen molecules. The catalytic activity of $\mathrm{Mn}$ (II) complex for coupling of benzaldehyde, phenylacetylene and piperidine in 1,4-dioxane has also been investigated and the maximum yield of propargylamine is up to $72.2 \%$ after $12 \mathrm{~h}$ at $120{ }^{\circ} \mathrm{C}$. Copyright (C) 2017 BCREC Group. All rights reserved
\end{abstract}

Keywords: Mn(II) complex; Phenanthroline; Catalytic activity; Mn(II) complex

How to Cite: Wang, L.H., Li, P.F. (2018). Synthesis, Structure, and Catalytic Activity of A New Mn(II) Complex with 1,4-Phenylenediacetic Acid and 1,10-Phenanthroline. Bulletin of Chemical Reaction Engineering \& Catalysis, 13 (1): 1-6 (doi:10.9767/bcrec.13.1.975.1-6)

Permalink/DOI: https://doi.org/10.9767/bcrec.13.1.975.1-6

\section{Introduction}

Studies on the design, synthesis and property of metal complex materials have been one of the most important research topics for chemists and materials scientists, because they exhibit not only novel topological structures [1-5], but also many potential applications in catalysis [6,7], luminescence [8,9], magnetic [10], antibacterial and antitumor [11-13], and gas storage [14]. It should be noted that the carboxylate ligands have often been used to synthesize func-

* Corresponding Author.

E-mail: wanglihua929@163.com (Wang, L.H.)

Telp.: +86-536-8785613; Fax.: +86-536-8785613 tional metal complexes, because the oxygen atoms of carboxylates are easy to coordinate with metal ions. Meanwhile, they may adopt monodentate coordination mode and bidentate coordination mode [15-18]. The 1,10phenanthroline is also used as secondary ligand to prevent the coordination of water molecules with metal ions [19-21]. Meanwhile, the complex catalysts show environmentally friendly and economical to synthesis of propargylamines comparing with conventional catalysts [22]. Based on the above reasons, in this work, we report a new Mn(II) complex, $\left\{\left[\mathrm{MnL}(\text { phen })_{2}\left(\mathrm{H}_{2} \mathrm{O}\right)\right] 0.5 \mathrm{~L} \cdot 6 \mathrm{H}_{2} \mathrm{O}\right\}$, which has been synthesized by one-pot reaction of 
$\mathrm{Mn}\left(\mathrm{CH}_{3} \mathrm{COO}\right)_{2} \cdot 4 \mathrm{H}_{2} \mathrm{O}, \quad$ 1,4-phenylenediacetic $\left(\mathrm{H}_{2} \mathrm{~L}\right)$, 1,10-phenanthroline (phen), and $\mathrm{NaOH}$ in water/ethanol $(\mathrm{v}: \mathrm{v}=1: 1)$ solution. The catalytic activity of $\mathrm{Mn}(\mathrm{II})$ complex for coupling of benzaldehyde, phenylacetylene, and piperidine in 1,4-dioxane has also been investigated.

\section{Materials and Methods}

\subsection{Materials and measurements}

The following chemical reagents used are analytical grade: 1,4-phenylenediacetic acid, 1,10-phenanthroline, $\mathrm{Mn}\left(\mathrm{CH}_{3} \mathrm{COO}\right)_{2} \cdot 4 \mathrm{H}_{2} \mathrm{O}$, $\mathrm{NaOH}$, piperidine, benzaldehyde, phenylacetylene, and 1, 4-dioxane.

Elemental analyses $(\mathrm{C}, \mathrm{H}$, and $\mathrm{N})$ were measured on an Elementar Vario III EL Elemental Analyzer. IR spectra were measured on a Nicolet AVATAR 360 infrared spectrometer in the 4000-400 $\mathrm{cm}^{-1}$ region. The crystal data of $\left.\left\{[\mathrm{MnL} \text { (phen })_{2}\left(\mathrm{H}_{2} \mathrm{O}\right)\right] 0.5 \mathrm{~L} .6 \mathrm{H}_{2} \mathrm{O}\right\}$ were collected by a Bruker Smart CCD diffractometer.

\subsection{Synthesis of $\left\{\left[\mathrm{MnL}(\text { phen })_{2}\left(\mathrm{H}_{2} \mathrm{O}\right)\right]\right.$ $\left.\cdot 0.5 \mathrm{~L} \cdot 6 \mathrm{H}_{2} \mathrm{O}\right\}$}

The 1.0 mmol $(0.192$ g) 1,4 phenylenediacetic, $1.0 \mathrm{mmol}(0.180 \mathrm{~g})$ 1,10- phenanthroline, $2.0 \mathrm{mmol}$ (0.080 g) sodium hydroxide, and $1.0 \mathrm{mmol}(0.245 \mathrm{~g})$ $\mathrm{Mn}\left(\mathrm{CH}_{3} \mathrm{COO}\right)_{2} \cdot 4 \mathrm{H}_{2} \mathrm{O}$ were added to the $15 \mathrm{~mL}$ of $\mathrm{CH}_{3} \mathrm{CH}_{2} \mathrm{OH} / \mathrm{H}_{2} \mathrm{O}$ (v:v=1:1) solution. The mixture was continuously stirred for $6 \mathrm{~h}$ at refluxing temperature, then the mixture was cooled to room temperature, and was collected by filtration. The single crystal suitable for X-ray determination was obtained from filtrate after 30 days by evaporation at room temperature.

\subsection{Crystal data and structure determina- tion}

The yellow block crystal of $\left\{\left[\mathrm{MnL}(\text { phen })_{2}\left(\mathrm{H}_{2} \mathrm{O}\right)\right] \cdot 0.5 \mathrm{~L} \cdot 6 \mathrm{H}_{2} \mathrm{O}\right\} \quad(0.28 \mathrm{~mm} \quad \times$ $0.24 \mathrm{~mm} \times 0.22 \mathrm{~mm}$ ) was mounted on a Bruker Amart CCD diffractometer equipped with a graphite-monochromatic $\operatorname{MoKa}(\lambda=0.71073 \AA)$ for the collection of intensity data. In the range of $3.32<\theta<25.01$, a total of 15510 reflections were collected and 6947 were independent with $R_{\text {int }}=0.0473$, of which 4859 were observed with $I>2 \sigma(I)$. The structure was solved by direct methods with SHELXS-97 [23] and refined by full-matrix least-squares techniques on $F^{2}$ with SHELXL-97 [24].

Table 1. Crystal data of $\left\{\left[\mathrm{MnL}(\mathrm{phen})_{2}\left(\mathrm{H}_{2} \mathrm{O}\right)\right] \cdot 0.5 \mathrm{~L} \cdot 6 \mathrm{H}_{2} \mathrm{O}\right\}$

\begin{tabular}{|c|c|}
\hline Empirical formula & $\mathrm{C}_{39} \mathrm{H}_{42} \mathrm{MnN}_{4} \mathrm{O}_{13}$ \\
\hline Formula weight & 829.71 \\
\hline Temperature/K & 293(2) \\
\hline Crystal system & triclinic \\
\hline Space group & $P-1$ \\
\hline$a / \AA$ & $10.703(2)$ \\
\hline$b / \AA ̊ ̊$ & $12.287(3)$ \\
\hline$c / \AA$ & $16.900(3)$ \\
\hline$\alpha /{ }^{\circ}$ & $69.25(3)$ \\
\hline$\beta /^{\circ}$ & $72.47(3)$ \\
\hline$\gamma /{ }^{\circ}$ & $86.72(3)$ \\
\hline Volume $/ \AA^{3}$ & 1978.7(7) \\
\hline$Z$ & 2 \\
\hline$\rho_{\text {calcmg }} / \mathrm{mm}^{3}$ & 1.393 \\
\hline$\mu / \mathrm{mm}^{-1}$ & 0.404 \\
\hline$S$ & 1.057 \\
\hline$F(000)$ & 866 \\
\hline Index ranges & $-12 \leq h \leq 12,-14 \leq k \leq 14,-20 \leq l \leq 18$ \\
\hline Reflections collected & 15510 \\
\hline Independent reflections & $6947[R(\mathrm{int})=0.0473]$ \\
\hline Data/restraints/parameters & $6947 / 0 / 514$ \\
\hline Goodness-of-fit on $F^{2}$ & 1.057 \\
\hline Final $R$ indexes $[I \geq 2 \sigma(I)]$ & $R_{1}=0.0785, w R_{2}=0.2140$ \\
\hline Final $R$ indexes [all data] & $R_{1}=0.0992, w R_{2}=0.2460$ \\
\hline
\end{tabular}




\section{Results and Discussion}

\subsection{Data of elemental analysis and IR spectrum}

The results of elemental analyses show that the $\mathrm{C}, \mathrm{H}$, and $\mathrm{N}$ are 56.41, 5.06, 6.75 (calc.) and $56.65,5.42,6.53$ (found), respectively. The characteristic IR bands of $\mathrm{Mn}(\mathrm{II})$ complex appears in $1635 \mathrm{~cm}^{-1}(\mathrm{C}=\mathrm{O})$ and $3423 \mathrm{~cm}^{-1}(\mathrm{H} 2 \mathrm{O})$.

\subsection{Structural description of $\left\{\left[\mathrm{MnL}(\text { phen })_{2}\right.\right.$ $\left.\left(\mathrm{H}_{2} \mathrm{O}\right)\right] \cdot 0.5 \mathrm{~L} \cdot 6 \mathrm{H}_{2} \mathrm{O}$ \}}

The crystal data of $\left\{\left[\mathrm{MnL}(\text { phen })_{2}\left(\mathrm{H}_{2} \mathrm{O}\right)\right]\right.$ $\left.\cdot 0.5 \mathrm{~L} \cdot 6 \mathrm{H}_{2} \mathrm{O}\right\}$ are given in Table 1 . One-pot reaction of $\mathrm{Mn}\left(\mathrm{CH}_{3} \mathrm{COO}\right)_{2} \cdot 4 \mathrm{H}_{2} \mathrm{O}, \quad 1,4$ phenylenediacetic $\left(\mathrm{H}_{2} \mathrm{~L}\right)$, 1,10-phenanthroline (phen), and $\mathrm{NaOH}$ in water/ethanol ( $\mathrm{v}: \mathrm{v}=1: 1)$ solution afforded colorless block crystals of $\mathrm{Mn}$ (II) complex. Single crystal analysis shows that the $\mathrm{Mn}$ (II) complex crystallizes in the triclinic space group $P$-1. The asymmetric unit contains a monodentate 1,4-phenylenediacetate ligand, two phen ligands, a coordinated water molecule, 0.5 uncoordinated 1,4phenylenediacetate ligand, and six uncoordinated water molecules (Figure 1).

It can be seen that the $\mathrm{Mn}$ (II) ion is sixcoordinated by four $\mathrm{N}$ atoms from two different phen ligands, one $\mathrm{O}$ atom from carboxylate group of 1,4-phenylenediacetate ligand, and one $\mathrm{O}$ atom from coordinated water molecule, resulting in a distorted octahedral geometry. The Mn-O distances are 2.099(3) $\AA$ and 2.147(3) $\AA$, respectively, and the $\mathrm{Mn}-\mathrm{N}$ dis-

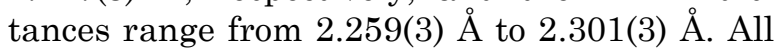
of which are consistent with those reported in

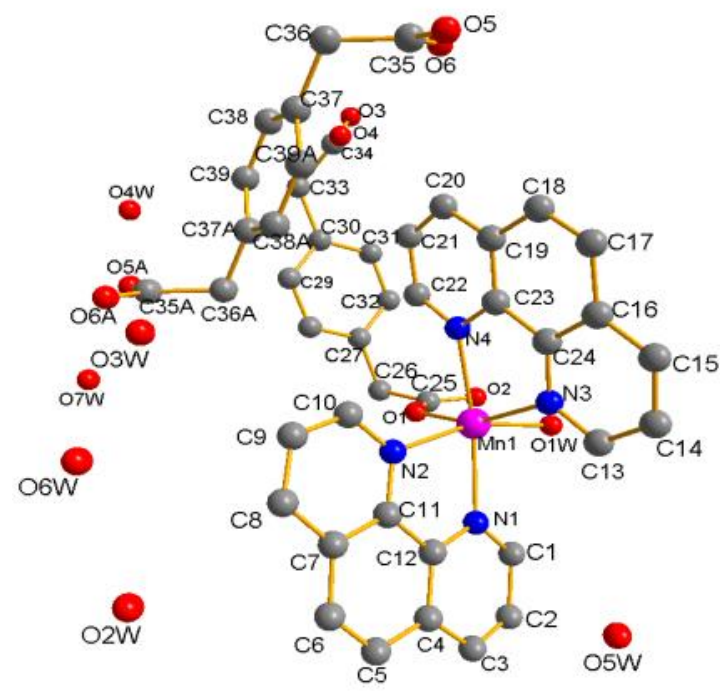

Figure 1. Molecular structure of $\mathrm{Mn}(\mathrm{II})$ complex the other Mn(II)-containing compound [25-28]. The important bond parameters of $\left\{\left[\mathrm{MnL}(\mathrm{phen})_{2}\left(\mathrm{H}_{2} \mathrm{O}\right)\right] \cdot 0.5 \mathrm{~L} \cdot 6 \mathrm{H}_{2} \mathrm{O}\right\}$ are listed in Table 2.

In addition, the $\mathrm{Mn}$ (II) complex molecules form 1D chain structure though the п-п interaction of phen ligands (Figure 2). As shown in Figure 2, the main chain is constructed by the phen ligands, the monodentate 1,4phenylenediacetate ligands are on both sides of chain. The 1D chains are connected by hydrogen bonds to form 3D network structure (Figure 3).

\subsection{Catalytic studies}

The catalytic activity of Mn(II) complex was tested for the preparation of propargylamine in the $\mathrm{A}^{3}$ coupling reaction. The coupling of benzaldehyde, piperidine and phenylacetylene with 1,4-dioxane as solvent was selected as a model reaction (Figure 3). The results are summarized in Table 3. It can be seen that $\mathrm{Mn}$ (II) complex has a good catalytic activity for the $\mathrm{A}^{3}$ coupling reaction of benzaldehyde, phenylacetylene, and piperidine with 1,4-dioxane as solvent at $120{ }^{\circ} \mathrm{C}$. Benzaldehyde conversion is $72.7 \%$ within $12 \mathrm{~h}$ at $120^{\circ} \mathrm{C}$ over $\mathrm{Mn}$ (II) complex. And the catalyst feature $100 \%$ selectivity to the product of propargylamine for the $\mathrm{A}^{3}$ coupling reaction without any byproduct. The catalytic activity of $\mathrm{Mn}$ (II) complex for the $\mathrm{A}^{3}$

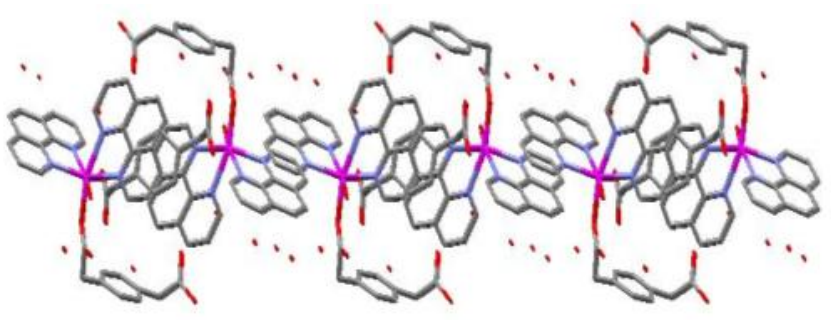

Figure 2. 1D chained structure of $\mathrm{Mn}(\mathrm{II})$ complex

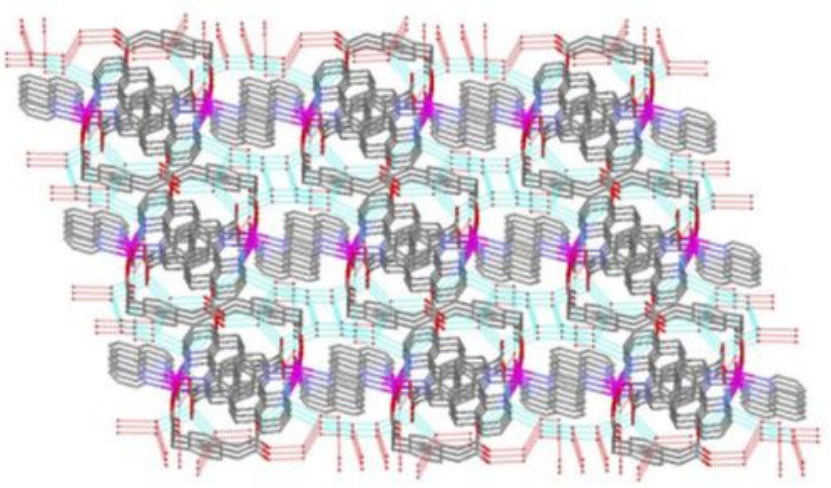

Figure 3. 3D network structure of Mn(II) complex 
Bulletin of Chemical Reaction Engineering \& Catalysis, 13 (1), 2018, 4

Table 2. The important bond parameters of $\left\{\left[\mathrm{MnL}(\text { phen })_{2}\left(\mathrm{H}_{2} \mathrm{O}\right)\right] \cdot 0.5 \mathrm{~L} \cdot 6 \mathrm{H}_{2} \mathrm{O}\right\}$

\begin{tabular}{llll}
\hline Bond & Distance $(\AA)$ & Angle & $\left({ }^{\circ}\right)$ \\
\hline Mn1-O1 & $2.099(3)$ & O1W-Mn1-O1 & $89.51(13)$ \\
Mn1-O1W & $2.147(3)$ & O1-Mn1-N4 & $89.00(13)$ \\
Mn1-N4 & $2.259(3)$ & O1W-Mn1-N4 & $106.59(14)$ \\
Mn1-N1 & $2.263(4)$ & O1-Mn1-N1 & $100.52(13)$ \\
Mn1-N3 & $2.282(4)$ & O1W-Mn1-N1 & $89.89(16)$ \\
Mn1-N2 & $2.301(3)$ & N1-Mn1-N4 & $161.13(15)$ \\
& & N3-Mn1-O1 & $160.66(13)$ \\
& & N3-Mn1-O1W & $88.37(13)$ \\
& & N3-Mn1-N4 & $73.23(13)$ \\
& & N1-Mn1-N3 & $98.70(13)$ \\
& & O1-Mn1-N2 & $98.86(11)$ \\
& & O1W-Mn1-N2 & $162.15(15)$ \\
& & N2-Mn1-N4 & $89.39(12)$ \\
& & N1-Mn1-N2 & $73.16(14)$ \\
& & N2-Mn1-N3 & $88.75(12)$ \\
\hline
\end{tabular}

Table 3. Coupling of benzaldehyde, phenylacetylene, and piperidine catalyzed by Mncomplex in 1,4-dioxane [a]

\begin{tabular}{ccccc}
\hline run & Solvent & Temperature $\left({ }^{\circ} \mathrm{C}\right)$ & Time $(\mathrm{h})$ & Conversion $(\%)^{[\mathrm{b}]}$ \\
\hline 1 & 1,4-dioxane & 120 & 12 & 72.2 \\
2 & 120 & 12 & 61.6 \\
3 & 1,4-dioxane & 120 & 12 & 52.6 \\
4 & 1,4-dioxane & 120 & 12 & 42.6 \\
\hline
\end{tabular}

[a]Reaction conditions: aldehyde $(0.13 \mathrm{mmol})$, amine $(0.15 \mathrm{mmol})$, alkyne $(0.17 \mathrm{mmol}), \mathrm{Mn}$-complex $(80 \mathrm{mg})$, dioxane $(1.5 \mathrm{~g})$;

[b] The products was determined by GC analysis of the samples (GC-1100, capillary column SE-54) using $n$ nonane as the external standard.

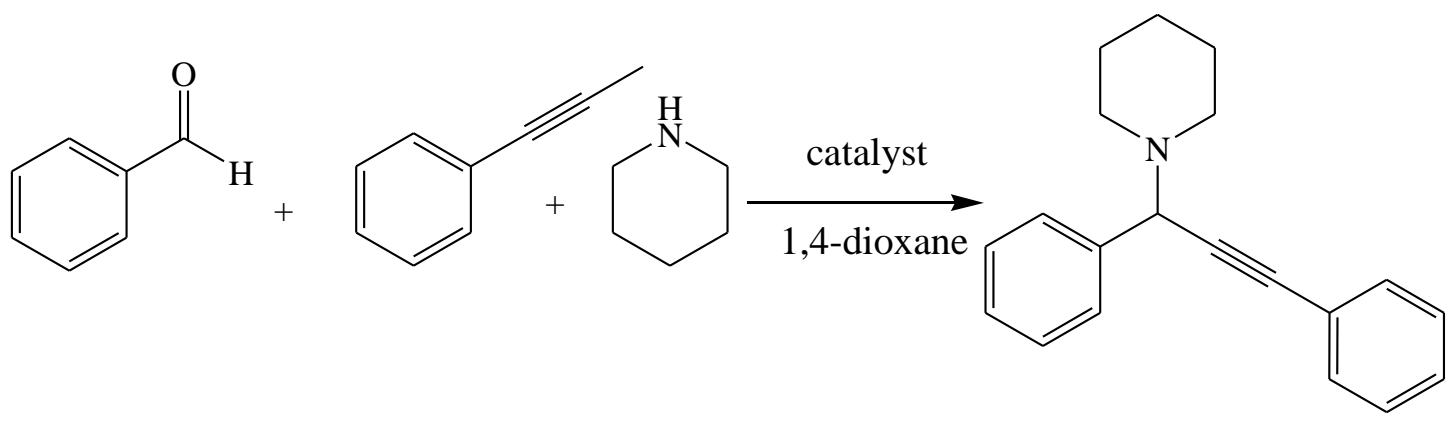

Figure 4. The coupling of benzaldehyde, piperidine, and phenylacetylene with 1,4-dioxane as solvent using $\mathrm{Mn}(\mathrm{II})$ complex as a catalyst 
coupling reaction of benzaldehyde, phenylacetylene, and piperidine is better than that of $\mathrm{Cu}$ (II) complex reported in ref. [7]. To check the reusability, the catalyst of $\mathrm{Mn}$ (II) complex was repeatedly filtered out and subjected to a new reaction batch without any further treatment. The catalyst of $\mathrm{Mn}(\mathrm{II})$ complex exhibited $61.6 \%$, $52.6 \%$, and $46.2 \%$ within $12 \mathrm{~h}$ at $120^{\circ} \mathrm{C}$ in the first, second, and third cycles, respectively. Clearly, the recovered catalyst features a significant deactivation by around $10.6 \%$ for the first run, while further recycling leads to $9.0 \%$ and $6.4 \%$ deactivation.

\section{Conclusions}

In summary, a new Mn(II) complex has been prepared and its structure has also been determined by elemental analysis, FTIR spectra, and single crystal X-ray diffraction. The $\mathrm{Mn}$ (II) complex exhibits good catalytic activity for $\mathrm{A}^{3}$ coupling reaction of benzaldehyde, piperidine, and phenylacetylene.

\section{Acknowledgement}

This project was supported by the National Natural Science Foundation of China (No. 21171132), the Natural Science Foundation of Shandong (ZR2014BL003), the project of Shandong Province Higher Educational Science and Technology Program (J14LC01) and Science Foundation of Weifang.

\section{References}

[1] Furukawa, H., Cordova, K.E., O'Keeffe, M., Yaghi, O.M. (2013). The Chemistry and Applications of Metal-Organic Frameworks. Science, 341: 1230444.

[2] Azarkish, M., Akbari, A., Sedaghat, T., Simpson, J. (2017). Heteroleptic Complexes of $\mathrm{Zn}(\mathrm{II})$ Based on 1-(5-Bromo-2h y d r o x y b e n z y li d e n e ) - 4 phenylthiosemicarbazide: Synthesis, Structural Characterization, Theoretical Studies and Antibacterial Activity. Journal of Molecular Structure, 1134: 126-134.

[3] Song, X.Z., Mu, W.S., Han, B.Y., Yan, Y. (2016). Synthesis, Structure and Photoluminescent Behavior of A Novel Pillar-Layered $\left\{\mathrm{Zn}_{3}\right\}$-based Metal-Organic Framework. Functional Materials Letters, 9: 1650002.

[4] Liu, J.W., Chen, L.F., Cui, H., Zhang, J.Y., Zhang, L., Su, C.Y. (2014). Applications of Metal-organic Frameworks in Heterogeneous Supramolecular Catalysis. Chemical Society Reviews, 43: 6011-6061.
[5] Bauer, H., Wallasch, M.W., Wolmershäuser, G., Sun, Y., Sitzmann, H. (2017). Iron(III) Half-Sandwich Complexes of the Two-Legged Piano-Stool [CpFe(aryl)Cl] Type from the Corresponding Aryliron(II) Precursors. European Journal of Inorganic Chemistry, 2017: 505-510.

[6] Devkule, S.S., More, M.S., Chavan, S.S. (2017). Synthesis, Characterization, Luminescence and Catalytic Properties of Copper(I) Complexes with N-(2 pyridylmethylene)-1,5-dimethyl-2-pyrazole-3(2H)-one and Triphenylphosphine as Ligands. Inorganica Chimica Acta, 455: 183-189.

[7] Wang, L.H., Liang, L., Wang, X. (2017). Synthesis, Structural Characterization and Catalytic Activity of A $\mathrm{Cu}(\mathrm{II})$ Coordination Polymer Constructed from 1,4-Phenylenediacetic Acid and 2,2'-Bipyridine. Bulletin of Chemical Reaction Engineering \& Catalysis, 12(1): 113118.

[8] Zhang, J., Zhu, X.J., Zhong, A.G., Jia, W.P., Wu, F.S., Li, D., Tong, H.B., Wu, C.L., Tang, W.Y., Zhang, P., Wang, L., Han, D.M. (2017). New Platinum(II) One-armed Schiff Base Complexes for Blue and Orange PHOLEDs Applications. Organic Electronics, 42: 153162.

[9] Chavan, S.S., Lolage, S.R., Pawal, S.B. (2016). Synthesis, Characterization and Luminescence Properties of Azobenzene Based Heterobimetallic Ru(II)/M(II) (M = Ni and Zn) Hybrid Complexes Composed of Organometallic and Coordination Sites. Journal of Organometallic Chemistry, 815-816: 65-73.

[10] Yang, F., Dong, Y.K., Guo, L.Y., Su, H.F., Jagličić, Z., Feng, Z.Y., Zhuang, G.L., Zeng, S.Y., Sun, D. (2016). Structural, Electrochemical and Magnetic Analyses of a New Octanuclear $\mathrm{Mn}^{\mathrm{II}_{2} \mathrm{Mn}^{\mathrm{II}}}$ Cluster with Linkeddefect Cubane Topology. CrystEngComm, 18: 1329-1336.

[11] Apohana, E., Yilmaz, U., Yilmaz, O., Serindag, A., Küçükbay, H., Yesilada, O., Baran, Y. (2017). Synthesis, Cytotoxic and Antimicrobial Activities of Novel Cobalt and Zinc Complexes of Benzimidazole Derivatives. Journal of Organometallic Chemistry, 828: 52-58.

[12] Heidari, F., Fatemi, J.A., Ebrahimipour, S.Y., Ebrahimnejad, H., Castro, J., Dušek, M., Eigner, V. (2017). Six-coordinate Oxovanadium(V) Dimer Complex with Methoxy Bridging: Synthesis, Crystal structure, Biological Activity and Molecular Docking. Inorganic Chemistry Communications, 76: 1-4.

[13] Tai, X.S., Wang, X. (2017). Synthesis, Structural Characterization and Antitumor Activity of a $\mathrm{Ca}(\mathrm{II})$ Coordination Polymer Based on 
4-Formyl-1,3-benzenedisulfonate-2-furoic Acid Hydrazide Ligands. Crystallography Reports, 62: 242-245.

[14] Lin, J.B., Zhang, J.P., Zhang, W.X., Xue, W., Xue, D.X., Chen, X.M. (2009). Porous Manganese(II) 3-(2-Pyridyl)-5-(4-Pyridyl)-1,2,4Triazolate Frameworks: Rational SelfAssembly, Supramolecular Isomerism, SolidState Transformation, and Sorption Properties. Inorganic Chemistry, 48: 6652-6660.

[15] Tai, X.S., Wang, X., Li, P.F. (2017). Synthesis, Crystal Structure, and Luminescent Property of a $\mathrm{Cd}(\mathrm{II})$ Coordination Polymer with a $\mathrm{N}$ Nicotinoylglycine Ligand. Crystals, 7: 33

[16] Bajpai, A., Chandrasekhar, P., Govardhan, S., Banerjee, R., Moorthy, J.N. (2015). Single Crystal-to-Single Crystal Site-Selective Postsynthetic Metal Exchange in a Zn-MOF Based on Semi-Rigid Tricarboxylic Acid and Access to Bimetallic MOFs. Chemistry - A European Journal, 21: 2759-2765.

[17] Li, T., Huang, X.H., Zhao, Y.F., Li, H.H., Wu, S.T., Huang, C.C. (2012). An Unusual Double T5(2) Water Tape Trapped in Silver(I) Coordination Polymer Hosts: Influence of the Solvent on the assembly of $\mathrm{Ag}(\mathrm{I})-4,4^{\prime}$ bipyridine Chains with Transcyclohexanedicarboxylate and Their Luminescent Properties. Dalton Transactions, 41: $12872-12881$.

[18] Yang, L.R., Liu, L., Lian, C., Liu, M.Y., Xu, Z.H., Wang, L.C., Guo, X., Long, Y.S. (2015). Zero-, One-, Two- and Three-dimensional Coordination Polymers Based on Tetracarboxylic Acid: Syntheses, Structures, Magnetic and Luminescent Properties. Dyes Pigments, 122: 246-256.

[19] Li, W.X., Zheng, Y.S., Cao, X.F., Bai, J., Fu, Z.F., Bai, J.R., Li, Y.L. (2016). Preparation, Characterization, and Luminescence Properties of Dysprosium Perchlorate with MABA-Si and Phen or Dipy Complexes as well as $\mathrm{SiO}_{2} @$ Dy(MABA-Si)L Core-shell Structure Nanometermeter Luminescent Composites. Journal of Luminescence, 178: 470-478.

[20] Bryleva, Y.A., (2014). Structure of [Dy(Phen) $\left.\left(\mathrm{C}_{4} \mathrm{H}_{8} \mathrm{NCS}_{2}\right)_{3}\right] \cdot 3 \mathrm{CH}_{2} \mathrm{Cl}_{2} \quad$ Solvate. Magnetic Properties and Photoluminiscence of $\left[\mathrm{Ln}(\mathrm{Phen})\left(\mathrm{C}_{4} \mathrm{H}_{8} \mathrm{NCS}_{2}\right)_{3}\right](\mathrm{Ln}=\mathrm{Sm}, \mathrm{Eu}, \mathrm{Tb}$, Dy, Tm) Complexes. Journal of Structural Chemistry, 55: 319-326.
[21] Fabio, M. Pettinari, R., Pettinari, C. (2015). Recent Advances in Acylpyrazolone Metal Complexes and Their Potential Applications. Coordination Chemistry Reviews, 303:1-31.

[22] Tai, X.S., Li, P.F., Wang, X., Liu, L.L. (2017). Synthesis, Structural Characterization, and Catalytic Property of A Zn(II) Complex with 5-Bromosalicylaldehyde Ligand. Bulletin of Chemical Reaction Engineering \& Catalysis, 12 (3): 364-369

[23] Sheldrick, G.M. (1997). SHELXL-97, Program for Crystal Structure Solution. University of Göttingen: Göttingen, Germany.

[24] Sheldrick, G.M. (1997). SHELXTL-97, Program for Crystal Structure Refinement. University of Göttingen: Göttingen, Germany.

[25] Wang, F.Y., Xi, Q.Y., Huang, K.B., Tang, X.M., Chen, Z.F., Liu, Y.C., Liang, H. (2017). Crystal structure, Cytotoxicity and Action Mechanism of $\mathrm{Zn}$ (II)/Mn(II) Complexes with Isoquinoline Ligands. Journal of Inorganic Biochemistry, 169: 23-31.

[26] Fan, Y., Si, C.D., Hou, C., Yao, X.Q., Hu, D.C., Yang, Y.X., Liu, J.C. (2015). Three Complexes of Manganese(II) Based on a New Semirigid Tetracarboxylate and $N$ Containing Ligands: Synthesis, Crystal Structures and Magnetic Properties. Polyhedron, 98: 64-70.

[27] Lv, Y., Shi, P., Shen, W., Chen, X.J., Zhao, G.L. (2015). A Series of Novel $\mathrm{Zn}(\mathrm{II})$ and $\mathrm{Mn}$ (II) Metal-organic Frameworks Constructed by 2,4-Bis-oxyacetate-benzoic Acid: Syntheses, Structures and Photoluminescence. Science China-Chemistry, 58: 448-456.

[28] Wu, H.L., Wang, X.L., Zhang, Y.H., Shi, F.R., Bai, Y.C., Wang, H., Pan, G.L. (2014). Synthesis, Structure, and DNA-binding Properties of Manganese(II) and Nickel(II) Complexes with Tris(N-ethylbenzimidazol-2ylmethyl)amine Ligand. Journal of Coordination Chemistry, 67: 660-669. 